\title{
Seasonality, biology and threats to Sicalis luteola (Sparrman, 1789) (Aves, Thraupidae) in northeastern Brazil
}

\author{
G. A. Pereira ${ }^{a}$, M. E. Larrazábal ${ }^{b}$ and S. M. Azevedo-Júnior ${ }^{a}$ \\ aPrograma de Pós-graduação em Etnobiologia e Conservação da Natureza, Departamento de Biologia, \\ Universidade Federal Rural de Pernambuco - UFPE, Rua Dom Manuel de Medeiros, s/n, CEP 52171-900, Recife, PE, Brazil \\ ${ }^{b}$ Departamento de Zoologia, Centro de Ciências Biológicas, Universidade Federal de Pernambuco - UFPE, \\ Avenida Professor Moraes Rego, 1235, Cidade Universitária, CEP 50670-420, Recife, PE, Brazil \\ *e-mail: glaucoapereira@yahoo.com.br
}

Received: June 15, 2015 - Accepted: January 11, 2016 - Distributed: May 31, 2017

(With 3 figures)

\begin{abstract}
Sicalis luteola occurs from Mexico to South America. In the Northeastern Brazilian region its biology, population dynamics and threats are poorly known. The subspecies $S$. luteola luteiventris apparently migrates northward during austral winter. The specific aims of this work were: 1) to verify the seasonality of the species; 2) to analyze information on molting and breeding, and 3) to check the main threats to this bird in northeastern Brazil. The highest number of records were in March, April, and May (51.12\%) and the lowest in November and December (3\%). We found a greater population peak in April in the states of Rio Grande do Norte and Ceará, and in April and May in Pernambuco. In Paraíba there was not an apparent seasonal variation in frequency. We captured 66 individuals, all adults, being 38 males and 28 females. $30 \%$ of the captured birds showed contour feathers molt, mainly on the head. A total of 23 individuals had brood patch, all being females. Six nests were found and four contained two to three eggs. We found that the main threat is the illegal trade. Our findings may support conservation plans for this bird in the region.
\end{abstract}

Keywords: Brazil, Caatinga, conservation, illegal trade.

\section{Sazonalidade, biologia e ameaças ao canário-tipio Sicalis luteola (Sparrman, 1789) (Aves, Thraupidae) no Nordeste do Brasil}

\section{Resumo}

Sicalis luteola ocorre do México a América do Sul. No Nordeste do Brasil sua biologia, dinâmica populacional e ameaças são pouco conhecidas. A subespécie S. luteola luteiventris aparentemente migra em direção ao norte durante o inverno austral. Os objetivos específicos deste trabalho foram: 1) verificar a sazonalidade da espécie, 2) obter informações referentes a muda e reprodução, e 3) verificar quais as principais ameaças. Os meses com os maiores números de registros foram março, abril e maio $(51,12 \%)$, enquanto os meses de novembro e dezembro foram os menos representativos (3\%). Foi encontrado um grande pico populacional no mês de abril nos estados do Rio Grande do Norte e Ceará, e em abril e maio em Pernambuco. Na Paraíba não houve uma variação sazonal marcante. Foram capturados 66 indivíduos, todos adultos, sendo 38 machos e 28 fêmeas. 30\% das aves capturadas apresentaram muda nas penas de contorno, principalmente na cabeça. Um total de 23 indivíduos apresentou placa de incubação, sendo todas fêmeas. Seis ninhos foram encontrados, quatro deles continham dois ou três ovos. A principal ameaça a espécie no Nordeste é o comércio ilegal de aves silvestres. Este trabalho fornece importantes ferramentas para subsidiar planos de conservação para essa ave na região.

Palavras-chave: Brasil, Caatinga, conservação, comércio ilegal.

\section{Introduction}

The Grassland Yellow-Finch (Sicalis luteola) inhabits part of Mexico, Central America and a large part of South America (Rising, 2011). It occurs in tall grassland, fields and edges of marshes (Ridgely and Tudor, 2009; Rising, 2011). This species is currently divided in eight subspecies (Rising, 2011), and in Brazil it is represented by half of them (Silveira and Méndez, 1999; Rising, 2011).

The subspecies $S$. luteola luteiventris occurs in the southern part of South America and apparently migrate northward during austral winter (Rising, 2011). In this time of the year they reach the central, north, midwest 
and northeast areas of Brazil (Sigrist, 2006). Studies on biology were published in Argentina and southeastern Brazil, mainly focused on reproductive aspects (Mason, 1985; Salvador and Salvador, 1986; De La Peña, 2010; Freitas and Francisco, 2012), however there is little clarity about the northern limit of its breeding area (Rising, 2011).

This bird is very sought after by breeders of wild birds in northeastern Brazil, being a popular cage bird and found in open markets (Pereira and Brito, 2005; Rising, 2011).

Therefore, we have carried out this research whose specific objectives were: a) to verify the seasonal variation of the species in northeastern Brazil, b) to analyze information on molting and breeding, and c) to check the main threats to $S$. luteola in Northeast Brazil.

\section{Material and Methods}

The information on S. luteola was collected in an opportunistic way in the eastern and northern states of the north-east Brazil (Ceará, Rio Grande do Norte, Pernambuco and Paraíba).

We obtained records by field work, literature surveys (Azevedo Júnior and Larrazábal, 2002; Olmos et al., 2005; Farias et al., 2005, 2010; Farias, 2007, 2009; Pereira, 2010; Pereira and Azevedo Júnior, 2013; Pereira et al., 2014), and through photos and sound records of the site WikiAves 'The Encyclopedia of the birds of Brazil' (WikiAves, 2015). Seasonal variation was analyzed by monthly quantitative records. Each documentation represented a record, and if multiple photos or recordings were performed by the same person or group of persons on the same day and same location, we also accept as only one record.

We proceed fieldwork between 26-29 March 2001, 23-26 April 2001, 27-29 April 2002 and 25-27 April 2003 in Salina Diamante Branco (05 05' 26”' S; $\left.36^{\circ} 16^{\prime} 31^{\prime \prime} \mathrm{W}\right)$, municipality of Galinhos, on the north coast of Rio Grande do Norte (Figure 1). In this locality there are coastal environment, temporary ponds and anthropogenic areas. The dominant vegetation cover is the Caatinga, which is seasonally dry and is formed mainly by thorny bushes (Ab’Sáber, 1977).

We mist-netted birds and checked for the occurrence of molt in the contour and flight feathers and the presence of brood patch. We banded captured with metal rings provided by the Centro Nacional de Pesquisa e Conservação de Aves Silvestres (CEMAVE/ICMBIO) according to the Wild Birds Ringing Manual (IBAMA, 1994). We did not consider recaptured birds for our analyses.

We also recorded information and evidences of capture, rearing and trade of the species in a database in order to evaluate the real threats of anthropogenic order. We visited some residences and open markets where the birds were sighted in cages to check the frequency that the species was reared or marketed in the region and to estimate, when possible, the capture method and the origin of the birds.

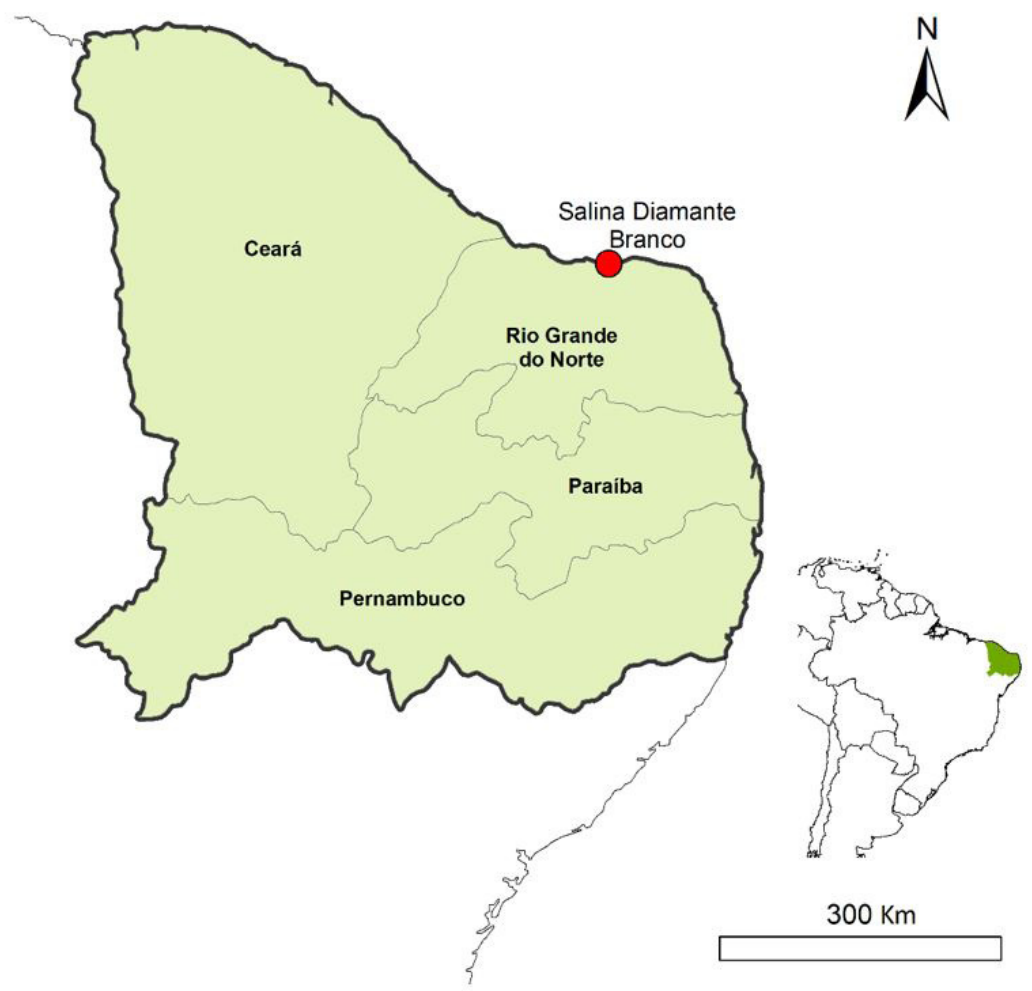

Figure 1. Location of the Salina Diamante Branco, Galinhos, state of Rio Grande do Norte, and the Brazilian states of Pernambuco, Paraíba and Ceará where Sicalis luteola was registered. 


\section{Results}

We sampled a total of 133 records of $S$. luteola in the four northeastern states. There was a greater concentration of records in April in Rio Grande do Norte, Ceará, and in April and May in Pernambuco. In Paraíba there was not a marked seasonal variation (Figure 2). The highest number of records were in March, April, and May (51.12\%) and the lowest in November and December (3\%) (Figure 3).

We captured 66 individuals, all adults, being 38 males and 28 females. None of the individuals captured had remiges or rectrices molts. On the other hand, $30 \%$ showed contour feathers molt, mainly on the head (Table 1).

Table 1. Quantity of specimens of Sicalis luteola having molt of contour feathers in Salina Diamante Branco, Rio Grande do Norte, Brazil. Body part: head, belly, and back.

\begin{tabular}{lccc}
\hline \multirow{2}{*}{ Date } & \multicolumn{3}{c}{$\begin{array}{c}\text { Contour feathers - molt } \\
\text { (number of individuals) }\end{array}$} \\
\cline { 2 - 4 } & Head & Belly & Back \\
\hline March/2001 & 2 & 0 & 1 \\
April/2001 & 12 & 0 & 0 \\
April /2002 & 4 & 3 & 0 \\
April /2003 & 2 & 0 & 2 \\
\hline
\end{tabular}

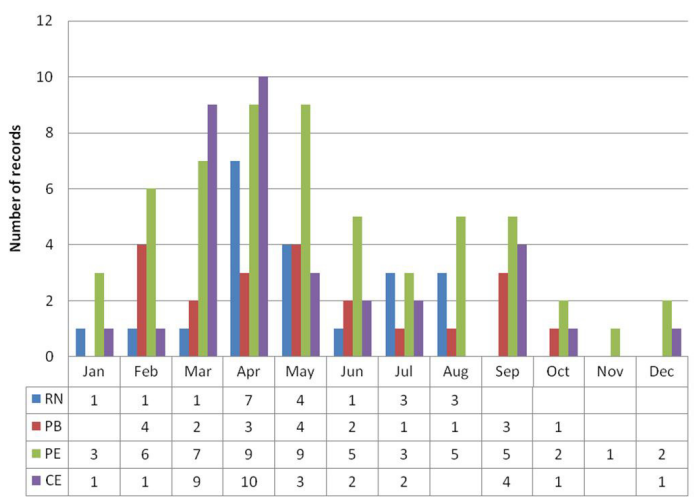

Figure 2. Variation in records of Sicalis luteola analyzed separately over the months in the states of Rio Grande do Norte (RN), Ceará (CE), Pernambuco (PE), and Paraíba (PB).

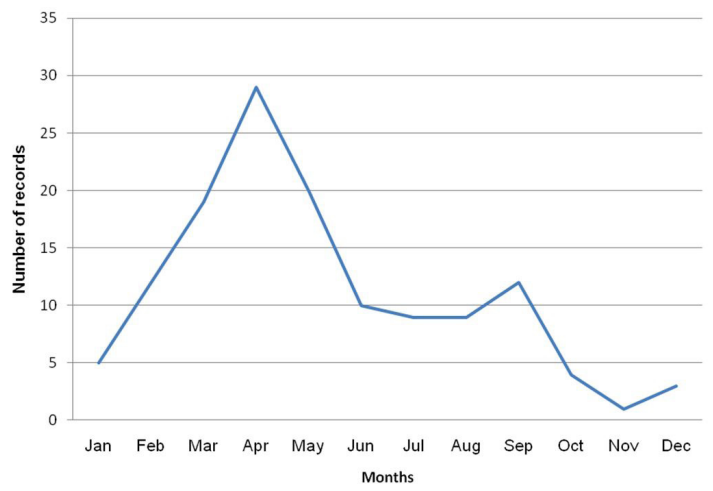

Figure 3. General variation of records of Sicalis luteola over the months in the states of Rio Grande do Norte, Ceará, Pernambuco, and Paraíba.
A total of 23 individuals had brood patch, all females. Six nests were found on a small island in an evaporation tank. These nests had the shape of a bulky cup, placed among the thickets of grass (Ciperacea), located a few inches off the ground. Four nests contained two to three eggs, but two of them contained four eggs.

We observed many cages with S. luteola in cities, such as Assú, Recife, Maceió, João Pessoa, Natal, João Câmara, and Campina Grande. Most of the breeders said that these birds were bought at fairs or from other breeders. However, three of them told us that they captured the birds. These captures were generally carried out using an individual in the cage (decoy), which attracted other individuals in freedom. These were caught in traps attached in the cage. Some people told us that when large flocks appeared, they captured many individuals using a special kind of glue (called visgo in Portuguese) that stuck the birds on a landing site.

We observed many individuals of this bird (approximately 100 individuals) being sold in the cities of Recife, Jaboatão dos Guararapes, and Campina Grande. They were in small compartments, without food and water and exposed to heat for many hours.

\section{Discussion}

The data from this study suggest that populations of S. luteola in northern and eastern parts of northeastern Brazil oscillate between months, and the peak of the movement occurs in March, April, and May, and after September the records become really scarce. The presence of brood patch only in females suggests that incubation is a function performed only by females, at least in this genus. In other works carried out in Argentina and southeastern Brazil, it was verified that only females of this species performed incubation (Salvador and Salvador, 1986; Freitas and Francisco, 2012).

The number of eggs found in the nests of this work was within the pattern for the species. In Argentina, almost 50 nests found had between two and six eggs in each (Salvador and Salvador, 1986; De La Peña, 2010). In southeastern Brazil there were four eggs per nest in 20 nests found (Freitas and Francisco, 2012).

Females with brood patch and nests with eggs were found in April. In the southeast and southern regions of Brazil there are nesting records between October and March (Belton, 1994; Freitas and Francisco, 2012). The breeding time in Rio Grande do Norte may be due to favorable ecological standards which this bird finds during migration, but this has not yet been reported in literature due to lack of specific works with this bird in the region. It is noteworthy that in the Caatinga many species of birds breed during the rainy season due to greater availability of resources (Araujo, 2009; Vilas-Bôas, 2013).

The populations of $S$. luteola in northeastern Brazil are constantly threatened by capture, trade and rearing. In Recife, for instance, several individuals were observed being sold in markets (Pereira and Brito, 2005). The different 
methods used to capture these birds can be seen in detail in a study performed in the northeastern semi-arid region (Bezerra et al., 2012). These captures and bird trade needs to be braked by environmental agencies, otherwise the populations of this species may suffer a decline in the future.

This study shows that the species is well distributed in northeastern Brazil with seasonal movements and reproduces in the region. In addition, this work brought some knowledge of biological data and threats of this bird. This information can be important for conservation of the species, if it become locally threatened in the future.

\section{Acknowledgements}

We thank John Medcraft for revising our translation and providing some important information on this bird in the State of Paraíba. Thanks also to the anonymous referees for their comments and suggestions.

\section{References}

AB'SÁBER, A.N., 1977. Espaços ocupados pela expansão dos climas secos na América do Sul, por ocasião dos períodos glaciais quaternários. Paleoclimas, vol. 3, pp. 1-19.

ARAUJO, H.F.P., 2009. Amostragem, estimativa de riqueza de espécies e variação temporal na diversidade, dieta e reprodução de aves em área de Caatinga, Brasil. João Pessoa: Universidade Federal da Paraíba, 198 p. PhD Thesis.

AZEVEDO JÚNIOR, S.M. and LARRAZÁBAL, M.E., 2002. Migração de aves em Pernambuco. In: J.M.C. SILVA and M. TABARELLI. Diagnóstico da biodiversidade da Caatinga. Recife: Massangana, vol. 2, pp. 623-630.

BELTON, W., 1994. Aves do Rio Grande do Sul: distribuição e biologia. São Leopoldo: UNISINO. 584 p.

BEZERRA, D.M.M., ARAUJO, H.F.P. and ALVES, R.R.N., 2012. Captura de aves silvestres no semiárido brasileiro: técnicas cinegéticas e implicações para a conservação. Tropical Conservation Science, vol. 5, no. 1, pp. 50-66.

DE LA PEÑA, M.R., 2010. Nidos de aves argentinas. Santa Fé: Universidad Nacional Del Litoral. CD-ROM.

FARIAS, G.B., 2007. Avifauna em quatro áreas de caatinga strictu senso no centro-oeste de Pernambuco, Brasil. Revista Brasileira de Ornitologia, vol. 15, no. 1, pp. 103-110.

FARIAS, G.B., 2009. Aves do Parque Nacional do Catimbau, Buíque, Pernambuco. Atualidades Ornitológicas, vol. 147, pp. 36-39.

FARIAS, G.B., PEREIRA, G.A. and BURGOS, K.Q., 2010. Aves da Floresta Nacional de Negreiros (Serrita, Pernambuco). Atualidades Ornitológicas, vol. 157, pp. 41-46.

FARIAS, G.B., SILVA, W.A.G. and ALBANO, C.G., 2005. Diversidade de aves em áreas prioritárias para a conservação da Caatinga. In: F.S. ARAÚJO, M.J.N. RODAL and M.R.V.
BARBOSA. Análise das variações da biodiversidade do bioma Caatinga: suporte a estratégias regionais de conservação. Brasília: Ministério do Meio Ambiente, pp. 206-228.

FREITAS, M.S. and FRANCISCO, M.R., 2012. Nesting behavior of the Grassland Yellow-Finch (Sicalis luteola) in southern Brazil. Ornitologia Neotropical, vol. 23, no. 3, pp. 341-348.

INSTITUTO BRASILEIRO DO MEIO AMBIENTE E RECURSOS NATURAIS RENOVÁVEIS - IBAMA, 1994. Manual de anilhamento de aves silvestres. 2nd ed. Brasília: IBAMA. $146 \mathrm{p}$.

MASON, P., 1985. The nesting biology of some passerines of Buenos Aires, Argentina. Ornithological Monographs, no. 36, pp. 954-972. http://dx.doi.org/10.2307/40168328.

OLMOS, F., SILVA, W.A.G. and ALBANO, C., 2005. Diversidade de aves em oito áreas de Caatinga no sul do Ceará e oeste de Pernambuco, Nordeste do Brasil: composição, riqueza e similaridade. Papéis Avulsos de Zoologia, vol. 45, no. 14, pp. 179-199. http:// dx.doi.org/10.1590/S0031-10492005001400001.

PEREIRA, G.A. and AZEVEDO JÚNIOR, S.M., 2013. Variação sazonal de aves em uma área de caatinga no Nordeste do Brasil. Ornitologia Neotropical, vol. 24, no. 4, pp. 387-399.

PEREIRA, G.A. and BRITO, M.T.B., 2005. Diversidade de aves silvestres brasileiras comercializadas nas feiras livres da Região Metropolitana do Recife, Pernambuco. Atualidades Ornitológicas, vol. 126 , pp. 14.

PEREIRA, G.A., 2010. Avifauna associada a três lagoas temporárias no estado do Rio Grande do Norte, Brasil. Atualidades Ornitológicas, vol. 156, pp. 53-60.

PEREIRA, G.A., MEDCRAFT, J., SANTOS, S.S. and FONSECANETO, F.P., 2014. Riqueza e conservação de aves em cinco áreas de caatinga no nordeste do Brasil. Cotinga, vol. 36, pp. 16-26.

RIDGELY, R.S. and TUDOR, G., 2009. Field guide to the songbirds of South America: the passerines. Austin: University of Texas Press. $750 \mathrm{p}$.

RISING, J.D., 2011. Family Emberizidae (bunting and new world sparrow). In: J. DEL HOYO, A. ELLIOT and D. CHRISTIE. Handbook of the birds of the world. Barcelona: Lynx Edicions, vol. 16, pp. 428-683.

SALVADOR, S.A. and SALVADOR, L.A., 1986. Nota sobre la reproducción del Misto (Sicalis luteola) em Córdoba, Argentina. El Hornero, vol. 12, no. 4, pp. 274-280.

SIGRIST, T., 2006. Aves do Brasil: uma visão artística. São Paulo: Forsfértil. 672 p.

SILVEIRA, L.F. and MÉNDEZ, A.C., 1999. Caracterização das formas brasileiras do gênero Sicalis (Passeriformes, Emberizidae). Atualidades Ornitológicas, vol. 90, pp. 6-8.

VILAS-BÔAS, M., 2013. Dinâmica reprodutiva de aves da Caatinga em uma área próxima ao Rio São Francisco. São Cristovão: Universidade Federal de Sergipe, 86 p. Masters Dissertation.

WIKIAVES [viewed 15 June 2015]. The Encyclopedia of the birds of Brazil [online]. 2015. Available from: www.wikiaves.com.br 


\section{Erratum}

In the article "Seasonality, biology and threats to Sicalis luteola (Sparrman, 1789) (Aves, Thraupidae) in northeastern Brazil", DOI http://dx.doi.org/10.1590/1519-6984.09215, published in Brazilian Journal of Biology, ahead of print, in the name of the second author:

Where it reads:

M. A. Larrazábal ${ }^{b}$

It should be read:

M. E. Larrazábal ${ }^{b}$ 